\title{
Black cumin Potential Anticancer effect of Black Cumin seed (Nigella sativa L.) extracts as determined by Cytotoxicity test against Larvae of Artemia salina Leach using Brine Shrimp Lethality Test (BSLT)
}

\author{
Rasidah $^{1 *}$, Vonna Aulianshah ${ }^{1}$ \\ ${ }^{1}$ Polythecnic Of Health, Department Of Pharmacy, Aceh, Indonesia
}

\begin{abstract}
Black cumin plant seed or black seed (Nigella sativa L.) is among the most commonly used spices. This plant is grown mostly for its spicy seeds. Studies have reported that black cumin seeds have high levels of antioxidant that correlates with anticancer activities. The current study aims to determine the cytotoxic effect of black seed extracts on brine shrimp larvae (Artemia salina Leach) using Brine Shrimp Lethality Test (BSLT). Black cumin seed extract was obtained through percolation method using an extraction solvent (ethanol 96\%). The cytotoxicity test was performed at $0 \mathrm{ppm}$ concentration (control) and 10 , $50,100,250$ and $500 \mathrm{ppm}$ concentrations of black seed extracts. We use 10 Brine Shrimp larvae per tube and repeated the test three times for each test group. Our results show that ethanolic extract (90\%) of black cumin seeds (Nigella sativa L.) has a strong cytotoxic effect on Artemia salina larvae with the $\mathrm{LC}_{50}$ value of $107.2 \mathrm{ppm}$.
\end{abstract}

Keywords : Cytotoxic, black cumin seed (Nigella sativa L.), Artemia salina Leach BSLT.

\section{Introduction}

Cancer is a leading cause of death worldwide, especially in North America, Australia, and Europe. As for Indonesia, cancer ranked third in terms of incidence. The most common treatment of cancer is chemotherapy. The problem experienced by cancer patients undergoing chemotherapy is that chemotherapy drugs kill not only cancerous cells but also the normal ones. This, in turn, causes other treatment-related problems, such as decreased organ function, hair loss, reduced hemoglobin, nausea and vomiting. ${ }^{1}$

These problems make patients anxious and afraid to undergo the therapy. Therefore, some of them choose alternative treatments instead. In addition, the high cost of cancer treatments and the fact that there are cases of cancers that can be cured with medicinal plants lead to growing shift toward alternative treatments with herbal medicine. ${ }^{2}$ 
One of the medicinal plants with the potential to inhibit the growth of cancer cells is Nigella sativa. Known also as black cumin, Nigella sativa is an annual flowering plant in the family Ranunculaceae. ${ }^{3}$ Black cumin seeds have long been used, especially in the Middle East and Southeast Asia, for its therapeutic benefits. Traditionally, black cumin seeds are used as diuretic, diaphoretic, anthelmintic, and carminative drugs. ${ }^{4}$ However, it has been reported in a number of studies that black cumin seeds have also anti-bacterial, antiparasitic, anti-inflammatory, immunomodulatory, antihypertensive, anti-tumor, antioxidant and anti-cancer properties. ${ }^{5,6}$ Phytochemical tests show that black cumin seeds contain essential oils, fatty acids, alkaloids, flavonoids, tannins, saponins and terpenoids. ${ }^{7,8,9}$

Mariod et al. (2009) reported that black cumin seed has a strong antioxidant activity after conducting DPPH and Beta Carotene-Linoleic Acid tests to determine the antioxidant activities of black seed extract. ${ }^{10}$ Other similar studies also stated that black seeds extract concentrations of 1\%,2\%,3\% 4\% and 5\% have strong antioxidant activities. ${ }^{11}$ The antioxidant activity of a test compound is predicted to correlate with anticancer (cytotoxic) activity. This accords with a theory stating that antioxidant activities of a compound may inhibit free radical chain reaction, an absorption of Reactive Oxygen Species that reduces the risk of cancer. ${ }^{12}$

The potential anticancer activities of black seeds remain largely undetermined. The available collection of literatures has not explain how to process black cumin seeds to generate optimum anticancer activity. ${ }^{13}$ Therefore, it is necessary to conduct preliminary research to determine the potential anticancer activity of black seed extracts by conducting cytotoxicity assay with Artemia salina larvae using BSLT (Brine Shrimp Lethality Test).

\section{Experiment}

\section{Materials}

Black cumin seeds (Nigella sativa L.), ethanol 96\%, aqua dest, seawater, aluminum foil, dimethylsulfoxide 1\% (DMSO 1\%).

\section{Test Object}

Artemia salina larvae are used as our test objects. They were obtained from the Regional Centre for Brackishwater Aquaculture Development (BBAP Ujung Batee, Aceh Besar) in the form of eggs for subsequent hatching.

\section{Preparation of Extracts}

The extract is prepared through percolation procedure to filter $400 \mathrm{~g}$ of black seed powder that has been macerated for 3 hours. The mass is then transferred into percolator; ethanol $96 \%$ is added in amount sufficient to soak the simplicia and the percolating fluid remains above the mass; the lid of the percolator is closed and then let it remains closed for 24 hours. Open the percolator lid and let the extract fluid drops at 20 drops per minute and add ethanol $96 \%$ repeatedly. Percolation is halted if the out flowing filtrates become colorless. The percolate is then evaporated by means of vacuum rotary evaporator to obtain a thick extract. ${ }^{14}$

\section{The Hatching of Artemia salina Eggs}

For Arthemia salina Leach, a vessel with two spaces is prepared. A lamp is placed to generate warm temperature for hatching in one space, a sufficient amount of sea water is poured into the other. 50-100 mg shrimp eggs were poured into sea water for hatching. The space that contains shrimp eggs is covered with aluminum foil, and the lamp is turn on for 48 hours for hatching. The 24 hours hatched larvae will tend to swim toward the light source. The shrimp larvae to be tested are taken up using pipette. ${ }^{15}$

\section{Procedure of Cytotoxicity Test}

Cytotoxicity test is conducted using BSLT method. The extract (test solution) is divided into 6 groups of concentration: $500 \mathrm{ppm}, 250 \mathrm{ppm}, 100 \mathrm{ppm}, 50 \mathrm{ppm}, 10 \mathrm{ppm}$, and $0 \mathrm{ppm}$. Then put the 48 -hours old Artemia salina larvae into the respective concentrations, each with 10 larvae. Do this three times (Triplo). The reaction tubes are placed in an open area for 24 hours. Count the surviving larvae in each reaction tube. The standardized 
criterion for ensuring the death of larvae is no movement during observation. Count the percentage of dead larvae and do a probit analysis to calculate the LC50. ${ }^{16}$

\section{Results and Discussion}

Cytotoxic activity test using the BSLT (Brine Shrimp Lethality Test) method was performed as a preliminary study of anticancer. The observation parameter is the death of Artemia salina larvae. Larvae are said to die if they do not respond to a touch. The results show that the death of Artemia salina increases with higher concentration of extracts (Table 1). The highest percentage of larval mortality was found in the extract concentration of $500 \mathrm{ppm}$, and the lowest percentage of larval mortality was found in the extract concentration of $10 \mathrm{ppm}$.

Tabel 1. Observation Result of Cytotoxic Test of Black Cumin Seed Extract (Nigella sativa L.) on Artemia salina Leach larvae.

\begin{tabular}{|l|l|l|l|}
\hline Treatment & $\begin{array}{l}\text { Concentration } \\
(\mathbf{p p m})\end{array}$ & $\begin{array}{l}\text { Average Larval } \\
\text { Mortality }\end{array}$ & $\begin{array}{l}\text { Percentage of Larval } \\
\text { Mortality (\%) }\end{array}$ \\
\hline Control (P0) & 0 & 0 & 0 \\
\hline Black Cumin Seed Extract (P1) & 10 & 1 & 10 \\
\hline Black Cumin Seed Extract (P2) & 50 & 3 & 30 \\
\hline Black Cumin Seed Extract (P3) & 100 & 5 & 50 \\
\hline Black Cumin Seed Extract (P4) & 250 & 7 & 70 \\
\hline Black Cumin Seed Extract (P5) & 500 & 8 & 80 \\
\hline
\end{tabular}

Differences in the percentage of larval mortality in table 1 might be caused by differences in the level of chemical compound of the extracts; the higher the extract concentration, the stronger the cytotoxic effect in the test solution would be. Several studies reported that black cumin seeds contain essential oils, fatty acids, alkaloids, flavonoids, tannins, saponins and terpenoids. ${ }^{7,89}$ No larval mortality was found in the control group (P0). This is because no extracts were added to the test solution of the control group. For this reason, it is safe to say that larval dead is caused solely by the addition of black cumin seed (Nigella sativa L.) extracts. Probit analysis (Table 2) is necessary to compute the LC50 of black cumin seed extracts administered to Artemia salina larvae.

From the data presented in Table 2, linear equation is obtained: $Y=1.28 x+2.40$, with LC50 value of $107.2 \mathrm{ppm}$. The obtained LC50 value indicates that the ethanolic extract of black seed (Nigella sativa L) is toxic and has potential anticancer properties because its LC50 value $<1000 \mathrm{ppm}^{17}$

Tabel 2. Data hasil perhitungan probit efek toksik ekstrak Biji Jintan Hitam (Nigella sativa L.)

\begin{tabular}{|l|l|l|l|}
\hline $\begin{array}{l}\text { Concentration } \\
(\mathbf{p p m})\end{array}$ & $\begin{array}{l}\text { log 10 } \\
(\text { Concentration) }\end{array}$ & $\begin{array}{l}\text { \% } \\
\text { Mortality }\end{array}$ & Probit \\
\hline 10 & 1 & 10 & 3.72 \\
\hline 50 & 1.699 & 30 & 4.48 \\
\hline 100 & 2 & 50 & 5 \\
\hline 250 & 2.398 & 70 & 5.52 \\
\hline 500 & 2.699 & 80 & 5.84 \\
\hline
\end{tabular}

The cytotoxicity of black cumin extract is tought to come from its content of Tymoquinone. Thymoquinone is a phytochemical compound belonging to class of terpenoids (monoterpene) found mostly in black cumin seeds by $\pm 7,8-13,7 \%$. ${ }^{18}$ Tymoquinone has been shown to have potential anti-cancer remedy, as has been proven in a number of studies. ${ }^{19}$ El-Najjar in Randhawa et al (2011) reported that Tymoquinone has been proven to inhibit the proliferation of human cancer cells (Caco-2, HCT-116, LoVo, DLD-1 dan HT-29). ${ }^{20}$ A 
study by Woo et al (2011) also provides evidence that Tymoquinone of black cumin seeds may inhibit the growth of breast cancer cells MCF-7, MDA-MB-231 dan BT-474. ${ }^{21}$ Tymoquinone is known to have an antiproliferation effect by reducing cell oxidative stress and, thus, triggering cell apoptosis. ${ }^{22,13}$

From this study it can be concluded that black cumin seeds exhibit toxicity against the larvae of Artemia salina Leach. However, further studies are necessary, especially those using cancer cell culture as the object of study. This preliminary study is expected to open up opportunities for black cumin seed extract to be used as a subject of anticancer research, considering that the pattern of larval development of Artemia salina is similar to that of cancer cells, which is fast and uncontrolled.

\section{Conclusion}

This study proves that black cumin seeds have toxicity against larvae of Artemia salina Leach with an $\mathrm{LC}_{50}$ value of $107.2 \mathrm{ppm}$.

\section{Recommendation}

We recommended future researches to focus on human cancer cell culture, both in vitro and in vivo, in order to determine the anticancer effect of black cumin seeds (Nigella sativa $\mathrm{L})$.

\section{References}

1. Setiawan, S.D. The Effect Of Chemotherapy In Cancer Patient To Anxiety. J Majority. 2015; 4(4): 9499.

2. Hasanah, S., Lucie, W. Herbal as A Compelementary Therapy for Tumor/cancer Patients. Jurnal Kefarmasian Indonesia. 2016;6(1): 49-59.

3. T.K. Lim. Edible Medicinal And Non-Medicinal Plant Volume 5 Fruits. Springer Since \& Business Media. 2013.

4. Gilani, A.H., Qaiser, J., Muhammad, A.U.K. A Review of Medicinal Uses and Pharmacological Activities of Nigella sativa. Pakistan Journal of Biological Sciences. 2004; 7(4):441-451.

5. Randhawa, M.A., M.S. Alhamdy. A Review of Pharmaco-therapeutic Effects of Nigella sativa. Pakistan J med. 2002; 41(2): 77-83.

6. Shoieb. A.M., Mona, E., Paul, S.D., Jonh, L.B., Patricia, K.T. In Vitro Inhibitor of Growth and Induction of Apoptosis in Cacer cell lines by Thymoquinon. International Journal of Oncology. 2003; 22(1): 107-113.

7. Takruri, H.R.H., Majdoleen, A.F.D. Study of the Nutrional Value of Blank Cumin Seeds (Nigella Sativa). Journal of the Science of Food and Agriculture. 1999; 7(3):404-410.

8. Mahmood, N., Nazir, R., Khan, M., iqbal, R., Adnan, M., Ullah, M., Yang, H. Phytochemical Screening, Antibacterial Activity and Heavy Metal Analysis of Ethnomedicinal Recipe and Their Sources Used Againt Infectious diseases. Plants. 2019; 8(453): 1-14.

9. Menounos, P., Kostis, S., Dina, D. The Sterols of Nigella sativa seed oil. Phytochemistry. 1986; 25(3):761-763.

10. Mariod, A. A. et al. Antioxidant activity and phenolic content of phenolic rich fractions obtained from black cumin (Nigella sativa) seedcake. Food Chemistry Elsevier Ltd. 2009; 116(1):. 306-312.

11. M A. . Awan, S. Akhter1 A. Azam, S. Qadeer, A. U. Husna, M. S. Ansari, B. A. R. Antioxidant activity of Nigella sativa Seeds Aqueous Extract and its use for cryopreservation of buffalo spermatozoa. Andrologia. 2018; 50(6): 1-7.

12. Hoshyar, R. et al. Correlation of Anticancer Effects of 12 Iranian Herbs on Human breast Adenocarcinoma cells with antioxidant Properties. Free Radicals and Antioxidants. 2015; 5(2): 65-73.

13. Mukhtar, H. et al. Nigella sativa L. Seed And Seed Oil: Potential Sources Of High-Value Components for Development of Functional Foods And Nutraceuticals/Pharmaceuticals. Journal of Essential Oil Research. 2019; 31(3): 171-183.

14. The Indonesian Ministry of Health. Materia Medika Indonesia. Volume VI. Jakarta: Directorate General of POM. 1995

15. Panggabean, M. G. L. Hatchery and Harvesting techniques of Artemia Salina. Oseana. 1984. 
16. Hadijanah, S. Uji Toksisitas Ekstrak Etanol Daun Bidara (Ziziphus mauritiana) Terhadap Larva Udang (Artemia salina Leach) dengan Metode Brine Shrimp Lethality Test (BSLT) 2018; 2(1): 25.

17. Malik, A. et al. Antidiabetic And Cytotoxic Activities Of Ethyl Acetate Extract Of Piper Betle Leaves. Journal of Physics: Conference Series. 2018 ; 1116(4): 0-7.

18. Botnick, I., Xue, W., Bar, E., Ibdah, M., Schwartz,A., Joel, D. M., Lev, E., Fait,A., Lewinsohn, E. Distribution of Primary and Specialized Metabolites in Nigella Sativa Seed, A Spice with Vast Traditional and Historical uses. Journal Molecules. 2012; 17(9); 45-52

19. Swamy, K.M., Muhammad, S.A. Natural Bio-Active Compounds Voleme 2: Chemistry, Pharmacology and Healt Care Pratices. Spriger: Singapura. 2019.

20. Randhawa, M.A., Matour, A.A., Anticancer activity of Nigella sativa (Black Seed-A Review. The American Journal of Chinese medicine. 2011; 39(6): 1075-1091.

21. Woo,C.C., Ser, Y.L., Veronica, G., Chun, W.Y., Gautam, S. Alan, P.K., Kwong, H.B.T. Anticancer Activity of Thymoquinone in Breast Cancer Cells: Possible Involvement of PPAR-Y Pathway. Biochemical Pharmacology. 2011;82(2011):464-475.

22. Fahmy, H. M. In vitro study of the cytotoxicity of thymoquinone/curcumin fluorescent liposomes. Naunyn-Schmiedeberg's Archives of Pharmacology. 2019; 392(11): 1465-1476.

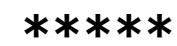

